\title{
Improvement in Flowability, Oxidation Resistance and Water Wettability of Graphite Powders by $\mathrm{TiO}_{2}$ Coating
}

\author{
Jingkun YU, Satoru UENO and Keisuke HIRAGUSHI \\ Okayama Ceramics Research Foundation, 1406-18, Nishikatakami, Bizen-shi 705
}

\section{チタニアコーティングによる黒鉛粉末の流動性，耐酸化性及び水に対するぬれ性の改善 于 景坤・上野 覚・平櫛敬資 \\ 岡山セラミックス技術振興財団, 705 備前市西片上 1406-18}

\begin{abstract}
Surface treatment is one of the most efficient ways to improve the water wettability, flowability and oxidation resistance of graphite powders used in castable refractories. In this study, the above properties of graphite powders coated with $\mathrm{TiO}_{2}$ (formed by heating $\mathrm{Ti}\left(\mathrm{OCH}_{2} \mathrm{CH}_{2} \mathrm{CH}_{2} \mathrm{CH}_{3}\right)_{4}$ at $120^{\circ} \mathrm{C}$ in air) were investigated. The results showed that the wettability and flowability of the graphite powders were greatly improved when the amount of $\mathrm{TiO}_{2}$ coated was more than 0.5 mass $\%$, and the oxidation resistance increased with increasing amount of $\mathrm{TiO}_{2}$ coated. The above improvement in the properties of the graphite powders was considered to be related to the changes in the size, shape and surface state of the powders.

[Received November 2, 1995; Accepted February 9, 1996]
\end{abstract}

\begin{abstract}
Key-words : Graphite powder, $\mathrm{TiO}_{2}$ coating, Organic compound of titanium, Wettability, Flowability, Oxidation
\end{abstract} resistance

\section{Introduction}

Graphite is widely used as a refractory material due to its many excellent properties such as high corrosion resistance and thermal shock resistance. However, because of its poor water wettability and flowability, it could not be used satisfactorily in castable refractories, in which it easily segregates thereby decreasing its advantageous effects.

In order to overcome the above drawbacks, measures such as surface treatments were adopted. Yoshimatsu et al. ${ }^{1)}$ investigated water wettability and oxidation resistance of $\mathrm{Al}_{2} \mathrm{O}_{3}$-coated graphite powders. Although the wettability and the oxidation resistance of the graphite powders were improved by coating with $\mathrm{Al}_{2} \mathrm{O}_{3}$, the flowability of the graphite powders was not.

As one of the fundamental studies aimed at the appropriate selection of oxide coatings, properties of graphite powders coated with $\mathrm{TiO}_{2}$ were investigated in this work.

\subsection{Raw materials}

\section{Experimental procedure}

The raw materials used in this work were natural flake graphite (purity: $98 \%$, average grain size: 50 $\mu \mathrm{m})$ and tetra- $n$-butoxy titanium; $\mathrm{Ti}\left(\mathrm{OCH}_{2} \mathrm{CH}_{2} \mathrm{CH}_{2}\right.$ $\left.\mathrm{CH}_{3}\right)_{4}$ (referred to as B-1 below, $\mathrm{TiO}_{2}$ content: 23.5 mass $\%$ ).

\subsection{Sample preparation and examination}

Various amounts (2.12-42.55 g) of B-1 were diluted with ethanol to $100 \mathrm{ml}$. The natural flake graphite powders $(500 \mathrm{~g})$ were coated with the above liquid in a Henschel mixer (1975 r.p.m. for $3 \mathrm{~min}$ ). The graphite powders before and after coating were dried in air at $120^{\circ} \mathrm{C}$ for $12 \mathrm{~h}$.

Properties of B-1 and the graphite powders after drying were examined by the following procedures.

(1) Behavior of B-1 during heating in air

B-1 was heated in air at a rate of $10^{\circ} \mathrm{C} / \mathrm{min}$ to $120^{\circ} \mathrm{C}$ and maintained at $120^{\circ} \mathrm{C}$ for $12 \mathrm{~h}$. The mass and heat changes were examined by thermogravimetry (TG) and differential thermal analysis (DTA), respectively.

(2) Size distribution

The size distribution of the graphite powders was determined by a laser diffraction particle size analyzer.

(3) Surface state of the graphite powders

The surface state of the graphite powders was observed by scanning electron microscopy (SEM) with energy-dispersed spectrometry (EDS).

(4) Wettability of the graphite powders

The graphite powders $(10 \mathrm{~g})$ were placed in water for $3 \mathrm{~h}$. The volume and mass of the sediment portion and the mass of the floating portion were determined, and then the volume of sediment and the fraction of floating were calculated by the following equations.

$$
\begin{aligned}
& \text { Volume of sediment }\left(\mathrm{m}^{3} / \mathrm{t}^{-1}\right) \\
& =\quad \text { (volume of sediment portion)/ } \\
& \quad \text { (mass of sediment portion) } \\
& \text { Fraction of floating (\%) } \\
& =\text { (mass of floating portion)/ } \\
& \quad \text { (total mass of powder) }
\end{aligned}
$$

Both indicate the water wettability of the graphite powders. With decreasing volume of sediment and fraction of floating, the water wettability was considered to improve. 
Thirty-gram of the graphite powders $\left(G_{0}\right)$ contained in a tea bag $\left(G_{1}\right)$ was placed in water for $3 \mathrm{~h}$ and the mass of the water-logged tea bag with the graphite powders $\left(G_{2}\right)$ was determined. The water content in the powders was then calculated according to

$$
\begin{aligned}
& \text { Water content }(\%) \\
& \quad=\left(G_{2}-G_{1}-G_{0}\right) /\left(G_{0}\right)
\end{aligned}
$$

which is considered to indicate the affinity between graphite powders and water.

(5) Flowability of the graphite powders

The flowability of the graphite powder with various amounts (0-110 mass\%) of water was determined according to JIS.2)

(6) Oxidation resistance of the graphite powders

The graphite powders were heated in air at a rate of $10^{\circ} \mathrm{C} / \mathrm{min}$ to $750^{\circ} \mathrm{C}, 800^{\circ} \mathrm{C}$ and $850^{\circ} \mathrm{C}$. The mass losses of the powders were recorded by $\mathrm{TG}$, and the oxidation ratio was calculated by the following equation.

$$
\begin{aligned}
& \text { Oxidation ratio }(\%) \\
& =(\text { mass loss } / \text { mass of graphite powders }) \\
& \quad \times 100
\end{aligned}
$$

(7) Specific surface area of the graphite powders

The specific surface area of the graphite powders was determined by the method of $\mathrm{N}_{2}$ adsorption (BET).

\section{Results}

3.1 Behavior of $\mathrm{B}-1$ during heating in air

Figure 1 shows the behavior of $\mathrm{B}-1$ during heating in air. The heat and mass changes were observed from room temperature. One endothermic peak at around $67^{\circ} \mathrm{C}$ was observed in the DTA curve. The mass loss of $\mathrm{B}-1$ after heating at $120^{\circ} \mathrm{C}$ for $6 \mathrm{~h}$ reached about 66 mass \%.

3.2 Effects of amount of $\mathrm{TiO}_{2}$ coated on the size and shape of the graphite powders

Figure 2 shows micrographs of the graphite powders coated with various amounts of $\mathrm{TiO}_{2}$ (provided that $\mathrm{B}-1$ was transformed completely to $\mathrm{TiO}_{2}$ ). With increasing amounts of $\mathrm{TiO}_{2}$, the size of graphite pow-

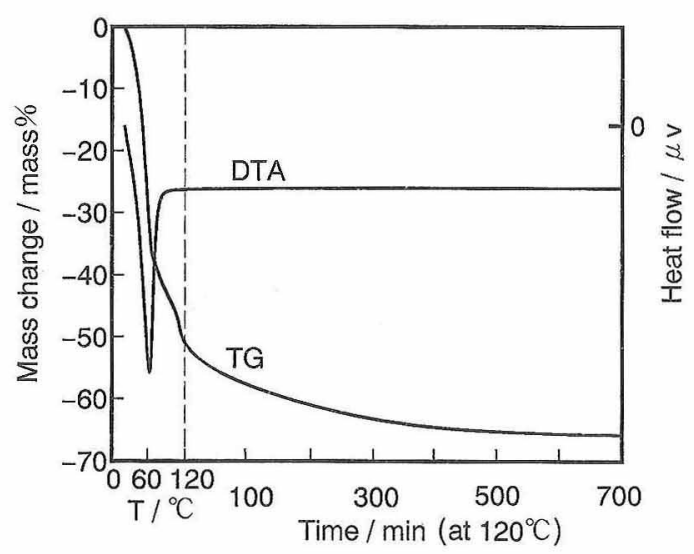

Fig. 1. TG and DTA curves of $\mathrm{B}-1$ (in air; $10^{\circ} \mathrm{C} / \mathrm{min}$ ).

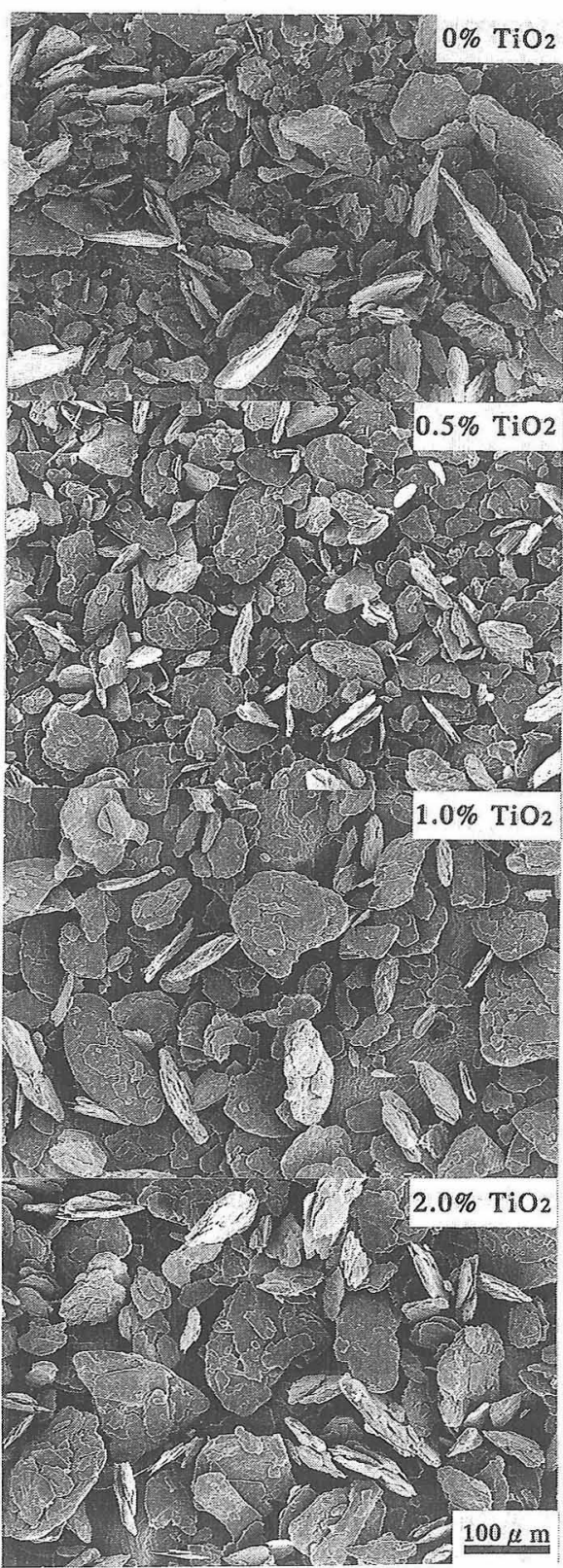

Fig. 2. Micrographs of the graphite powders coated with various amounts of $\mathrm{TiO}_{2}(0-2$ mass\%).

ders increased and became uniform. At the same time, the graphite powders became gradually rounded. Figure 3 shows the size distribution of the graphite powders. The size of graphite powders coated with $\mathrm{TiO}_{2}$ (curves 2-4) became more uniform than that of the graphite powders without coating (curve 1), but the maximum size of the graphite powders coated with $\mathrm{TiO}_{2}$ was the same as that of the graphite powders without coating.

\subsection{Distribution of $\mathrm{TiO}_{2}$ on the surface of the} graphite powders

Figure 4 shows micrographs of the surfaces of the graphite powders coated with various amounts of $\mathrm{TiO}_{2}\left(0-2\right.$ mass\%). As shown in the figures, $\mathrm{TiO}_{2}$ was evenly distributed on the surfaces of the graphite powders and the thickness of the $\mathrm{TiO}_{2}$ layer 


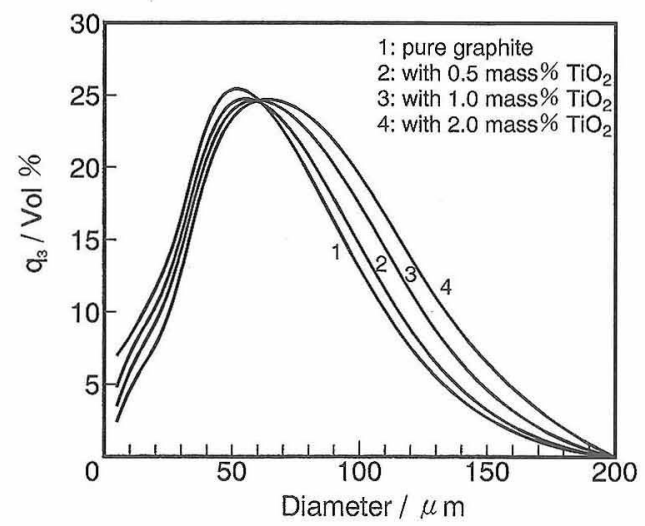

Fig. 3. Effect of the amount of $\mathrm{TiO}_{2}$ coating on size distribution of the graphite powders.

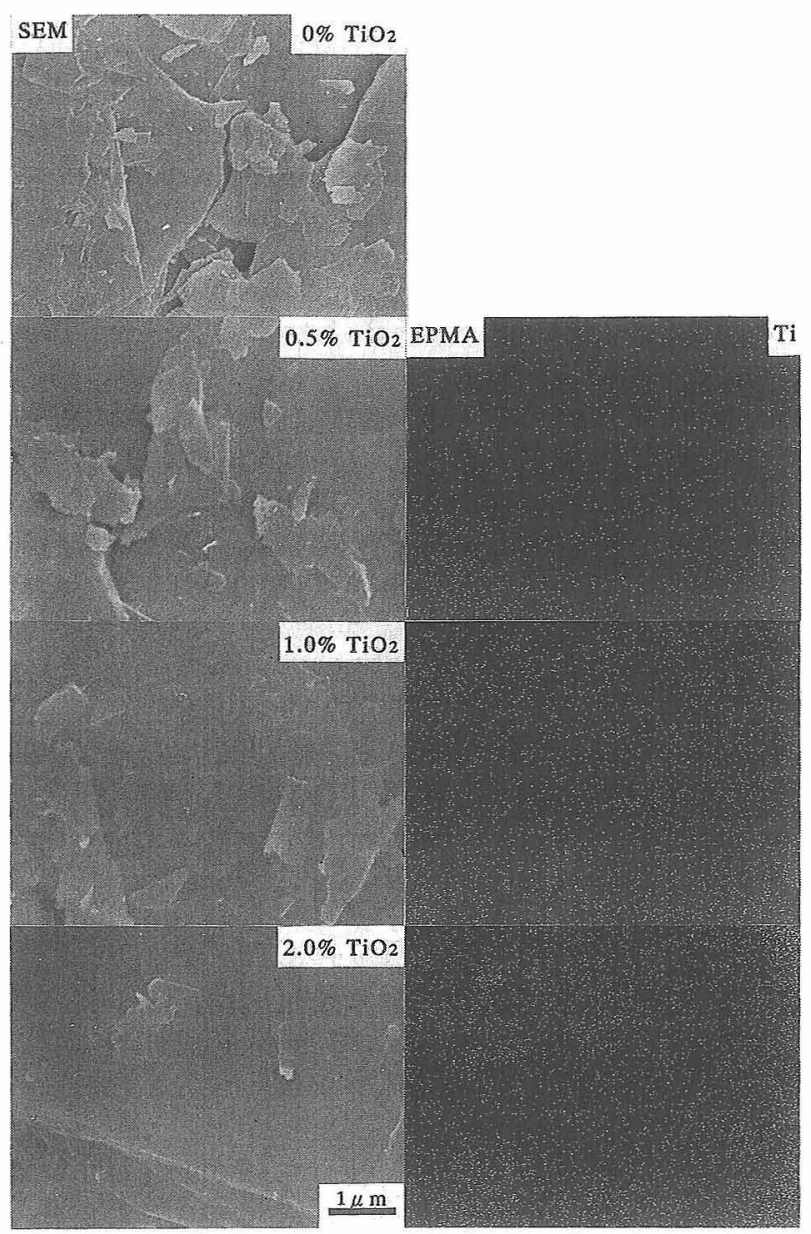

Fig. 4. SEM micrographs of surfaces of the graphite powders coated with various amounts of $\mathrm{TiO}_{2}(0-2$ mass\%).

increased with increasing amount of $\mathrm{TiO}_{2}$. In addition, most of the edges of the graphites were covered. Figure 5 shows micrographs of the surface of the graphite powders coated with 2 mass $\% \mathrm{TiO}_{2}$ after immersion in water for $3 \mathrm{~h}$. As shown in the figure, $\mathrm{TiO}_{2}$ coating was not difference from that before immersion in water (Fig. 4).

3.4 Effect of amount of $\mathrm{TiO}_{2}$ coated on the wettability of the graphite powders

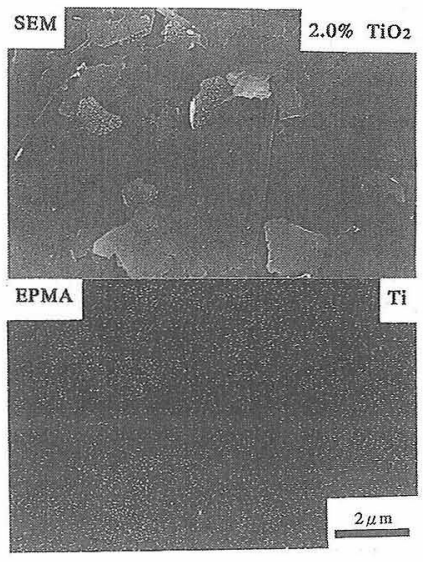

Fig. 5. SEM micrographs of surface of the graphite powders after immersion in water for $3 \mathrm{~h}$.

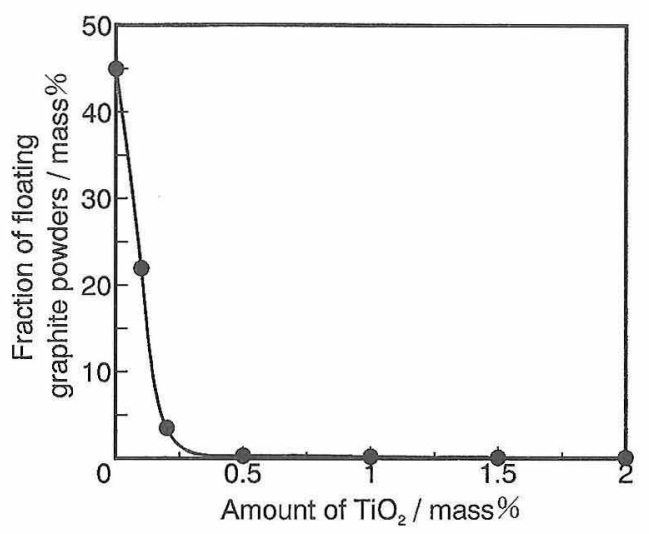

Fig. 6. Fraction of the floating graphite powders as a function of the amount of coated $\mathrm{TiO}_{2}$.

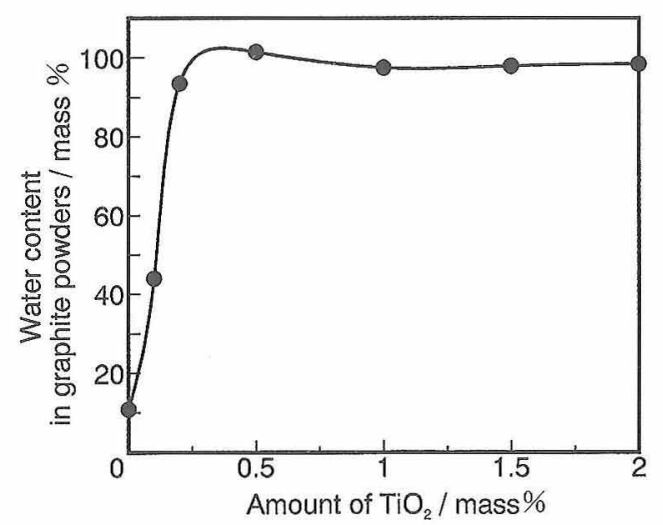

Fig. 7. Water content in the graphite powders as a function of the amount of coated $\mathrm{TiO}_{2}$.

Figures 6 and 7 show the fraction of floating graphite powders and the water content in the graphite powders, respectively. The fraction of floating graphite powders was close to 0 mass $\%$ and the water content to 100 mass $\%$ when the amount of $\mathrm{TiO}_{2}$ was more than 0.5 mass $\%$.

Figure 8 shows the volume of the sediment graphite powders relative to the amount of $\mathrm{TiO}_{2}$. The volume decreased by $45 \%$ when the amount of 


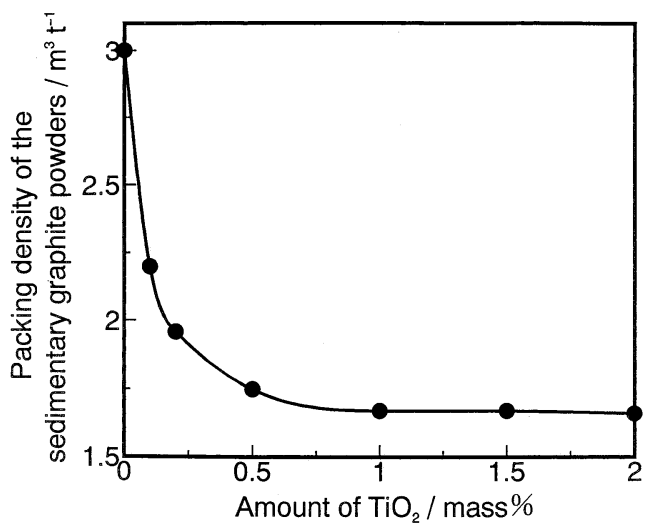

Fig. 8. Volume of sediment portion of graphite powders as a function of the amount of coated $\mathrm{TiO}_{2}$.

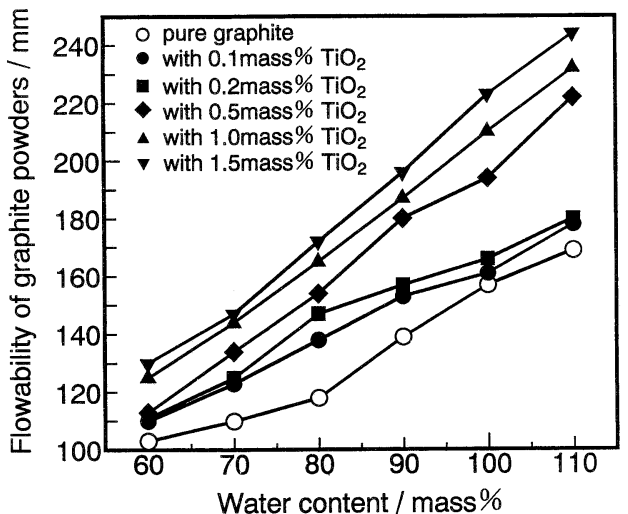

Fig. 9. Effects of the amount of coated $\mathrm{TiO}_{2}$ and water content on the flowability of graphite powders.

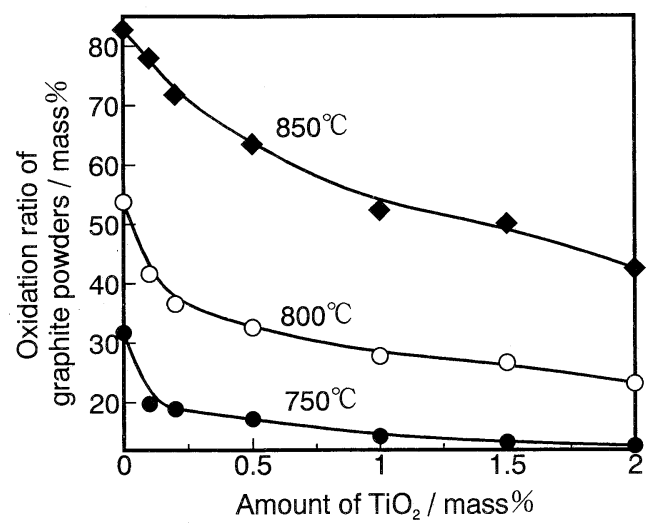

Fig. 10. Effects of the amount of coated $\mathrm{TiO}_{2}$ and temperature on the oxidation ratio of graphite powders.

$\mathrm{TiO}_{2}$ was more than 0.5 mass $\%$.

\subsection{Effect of amount of $\mathrm{TiO}_{2}$ coated on the flowability of the graphite powders}

Figure 9 shows changes in the flowability of the graphite powders with amount of $\mathrm{TiO}_{2}$. The flowability of the graphite powders was greatly improved by coating more than 0.5 mass $\%$ of $\mathrm{TiO}_{2}$. For example, at the water content of 80 mass $\%$, the flowability of as-received graphite powders was $118 \mathrm{~mm}$, whereas that of the graphite powders coated with 0.5 mass $\%$ of $\mathrm{TiO}_{2}$ increased to $154 \mathrm{~mm}$.

3.6 Effect of amount of $\mathrm{TiO}_{2}$ coated on the oxidation resistance of the graphite powders

Figure 10 shows the oxidation ratio of the graphite powders heated in air at $10^{\circ} \mathrm{C} / \mathrm{min}$ to $750^{\circ} \mathrm{C}$, $800^{\circ} \mathrm{C}$ and $850^{\circ} \mathrm{C}$. The oxidation ratio of the graphite powders decreased with increasing amount of $\mathrm{TiO}_{2}$. For example, when heated to $850^{\circ} \mathrm{C}, 82.80$ mass $\%$ of the graphite powders without coating was oxidized, whereas only $63.55,52.33$ and 42.44 mass\% of the graphite powders coated with $0.5,1.0$ and 2.0 mass\% of $\mathrm{TiO}_{2}$, respectively, were oxidized.

3.7 Change in the specific surface area of the graphite powders

The specific surface areas of the graphite powders coated with $0,0.5$ and 1.0 mass $\%$ of $\mathrm{TiO}_{2}$ were determined. The specific surface area of the graphite powders without coating was $2.38 \mathrm{~m}^{2} / \mathrm{g}$, whereas that of the graphite powders coated with 0.5 and 1.0 mass\% of $\mathrm{TiO}_{2}$ increased to 2.98 and $3.41 \mathrm{~m}^{2} / \mathrm{g}$, respectively.

\section{Discussion}

\subsection{Transformation of $\mathrm{B}-1$ to $\mathrm{TiO}_{2}$-Formation} of $\mathrm{TiO}_{2}$ coating

The formation of $\mathrm{TiO}_{2}$ coating on the surfaces of the graphite powders was mainly affected by the reaction processes of B-1 during heating in air. In accordance with the discussion in Ref. $3, \mathrm{~B}-1$ reacted initially with water vapor in air at room temperature according to reactions (4) and (5). The reaction products further reacted with each other or with the residual B-1 to form polymers according to reactions (6), (7) and (8). Finally, the polymers formed decomposed into $\mathrm{TiO}_{2}$ according to reaction (9).

$$
\begin{aligned}
& \left(\mathrm{C}_{4} \mathrm{H}_{9} \mathrm{O}\right)_{4} \mathrm{Ti}+\mathrm{H}_{2} \mathrm{O} \\
& \rightarrow\left(\mathrm{C}_{4} \mathrm{H}_{9} \mathrm{O}\right)_{3} \mathrm{TiOH}+\mathrm{C}_{4} \mathrm{H}_{9} \mathrm{OH} \\
& \left(\mathrm{C}_{4} \mathrm{H}_{9} \mathrm{O}\right)_{4} \mathrm{Ti}+2 \mathrm{H}_{2} \mathrm{O} \\
& \rightarrow\left(\mathrm{C}_{4} \mathrm{H}_{9} \mathrm{O}\right)_{2} \mathrm{Ti}(\mathrm{OH})_{2}+2 \mathrm{C}_{4} \mathrm{H}_{9} \mathrm{OH} \\
& \left(\mathrm{C}_{4} \mathrm{H}_{9} \mathrm{O}\right)_{3} \mathrm{TiOH}+\mathrm{HOTi}\left(\mathrm{OC}_{4} \mathrm{H}_{9}\right)_{3} \\
& \rightarrow\left(\mathrm{C}_{4} \mathrm{H}_{9} \mathrm{O}\right)_{3} \mathrm{Ti}-\mathrm{O}-\mathrm{Ti}\left(\mathrm{OC}_{4} \mathrm{H}_{9}\right)_{3}+\mathrm{H}_{2} \mathrm{O} \\
& \left(\mathrm{C}_{4} \mathrm{H}_{9} \mathrm{O}\right)_{4} \mathrm{Ti}+\mathrm{HOTi}\left(\mathrm{OC}_{4} \mathrm{H}_{9}\right)_{3} \\
& \rightarrow\left(\mathrm{C}_{4} \mathrm{H}_{9} \mathrm{O}\right)_{3} \mathrm{Ti}-\mathrm{O}-\mathrm{Ti}\left(\mathrm{OC}_{4} \mathrm{H}_{9}\right)_{3} \\
& \quad+\mathrm{C}_{4} \mathrm{H}_{9} \mathrm{OH}
\end{aligned}
$$

$$
\left(\mathrm{C}_{4} \mathrm{H}_{9} \mathrm{O}\right)_{3} \mathrm{Ti}-\mathrm{O}-\mathrm{Ti}\left(\mathrm{OC}_{4} \mathrm{H}_{9}\right)_{3} \stackrel{\left(\mathrm{C}_{4} \mathrm{H}_{9} \mathrm{O}\right)_{3} \mathrm{TiOH}}{\longrightarrow}
$$$$
\mathrm{Ti}\left[\mathrm{O}-\mathrm{Ti}\left(\mathrm{OC}_{4} \mathrm{H}_{9}\right)_{2}\right]_{n} \mathrm{OTi}\left(\mathrm{OC}_{4} \mathrm{H}_{9}\right)_{3}
$$

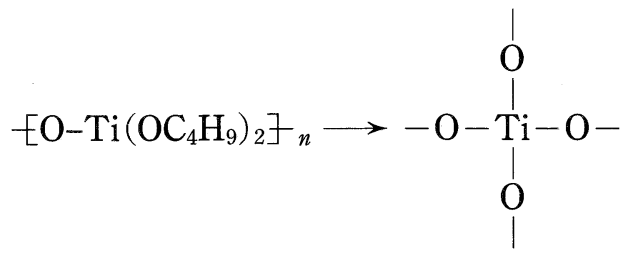

With increasing temperature from room temperature to about $67^{\circ} \mathrm{C}$, the rates of Reactions (4) to (9) increased rapidly; therefore, large mass and heat 
changes were observed in TG and DTA curves, respectively. However, when temperatures exceeded $67^{\circ} \mathrm{C}$, because the pressure of water vapor in the heating furnace was decreased greatly, the mass loss of B-1 increased slowly with temperature and time at $120^{\circ} \mathrm{C}$ (Fig. 1). After $6 \mathrm{~h}$ at $120^{\circ} \mathrm{C}$, the mass loss of B-1 tended to become constant, 66 mass \% (Fig. 1). This value was smaller than the 76.5 mass $\%$ corresponding to the complete transformation of B-1 to $\mathrm{TiO}_{2}$. This indicated that the transformation of $\mathrm{B}-1$ to $\mathrm{TiO}_{2}$ at low temperature was incomplete; in other words, the intermediate products which contained chemically sorbed water (see reactions (4) to (8)) remained in the coating.

If the coating was composed of only $\mathrm{TiO}_{2}, \mathrm{TiO}_{2}$ was distributed evenly, and its density was about $2.8 \mathrm{~g} / \mathrm{cm}^{3}$. Based on the specific surface area of the graphite powders, the thickness of the coating on the specific surfaces of the graphite powders was about $1.6 \mathrm{~nm}$ when the amount of $\mathrm{TiO}_{2}$ coated was 1 mass $\%$. However, according to the results in the Section 3.7 , by coating 0.5 and 1.0 mass $\% \mathrm{TiO}_{2}$, the specific surface area of the graphite powders increased by 0.60 and $1.03 \mathrm{~m}^{2} / \mathrm{g}$, respectively. If the increase in the specific surface area of the graphite powders were due to the formation of $\mathrm{TiO}_{2}$ on the graphite powders, the average specific surface area of $\mathrm{TiO}_{2}$ formed on the surface of the graphite powders should be $111.50 \mathrm{~m}^{2} / \mathrm{g}$. Because the coating formed was porous and contained chemically sorbed water, as stated above, the coating should in fact be thicker than $1.6 \mathrm{~nm}$. The formation of the porous coating was considered to be related to the low heating temperature $\left(\sim 120^{\circ} \mathrm{C}\right)$ at which, the $\mathrm{TiO}_{2}$ formed was not yet sintered.

4.2 Effect of $\mathrm{TiO}_{2}$ coating on the properties of the graphite powders

(1) Oxidation resistance

The improvement in the oxidation resistance of the graphite powders was related to the change in the surface state of the powders.

On the surfaces of the graphite powders, there exist many defects such as edges which are usually occupied by $\mathrm{H}, \mathrm{OH}$ and $\mathrm{O} .{ }^{4)}$ Oxidation of the graphite powders occurs initially at these defects. ${ }^{5)}$

As shown in Fig. 4, the surfaces of the graphite powders were evenly covered by $\mathrm{TiO}_{2}$. During heating, $\mathrm{B}-1$ reacted easily with the $\mathrm{H}, \mathrm{OH}$ and $\mathrm{O}$ atoms which occupy the defects on the surfaces of the graphite powders. ${ }^{6)}$ The reaction products formed mainly chemical bonds with the surfaces of the graphite powders. Thus, defects such as edges were covered and the $\mathrm{H}, \mathrm{OH}$, and $\mathrm{O}$ atoms were desorbed. As a result, the oxidation of the graphite powders was inhibited (Fig. 10).

\section{(2) Flowability}

The flowability of particles was affected by many factors, e.g., size, shape and surface state. When the particle size was less than $100 \mu \mathrm{m}$, the flowability of the particles was increased by increasing the particle size or by improving the smoothness of the surfaces of the particles. ${ }^{7), 8)}$ Furthermore, spherical particles showed good flowability. ${ }^{9}$ ) As shown in Figs. 2, 3 and 4, upon coating with $\mathrm{TiO}_{2}$, the size of the graphite powders increased, the graphite powders became rounded, and the surfaces of the graphite powders became smooth. These changes contributed to the improvement in the flowability of the graphite powders (Fig. 9).

\section{(3) Wettability}

On the surface of $\mathrm{TiO}_{2}$, there exist many unsaturated $\mathrm{Ti}$ atoms which easily combine with $\mathrm{O}$ atoms in water ${ }^{10)}$ to form $\mathrm{Ti}-\mathrm{OH}$ layers, on the surfaces of which, 2-3 layers of physically sorbed water are further formed. ${ }^{11)}$ In addition, because the $\mathrm{TiO}_{2}$ layer coated on the surfaces of the graphite powders was porous, water was easily absorbed.11) For these reasons, the graphite powders coated with $\mathrm{TiO}_{2}$ showed good wettability (Figs. 6, 7 and 8).

According to the above discussion, because the coating formed many chemical bonds with the graphite powders, the $\mathrm{TiO}_{2}$ coating on the surface of the graphite powders was stable. There was no difference in the surface of the graphite powders before or after immersion in water (Fig. 5).

\section{Conclusions}

The wettability, flowability and oxidation resistance of graphite powders coated with $\mathrm{TiO}_{2}$ were investigated in detail. The conclusions are as follows.

(1) The wettability and flowability of the graphite powders were greatly improved when the amount of $\mathrm{TiO}_{2}$ was more than 0.5 mass $\%$.

(2) The oxidation resistance of the graphite powders increased with increasing amount of $\mathrm{TiO}_{2}$.

\section{References}

1) H. Yoshimatsu, S. Fujiwara, R. Konishi, M. Miyawaki and Y. Miura, J. Ceram. Soc. Japan, 103, 929-34 (1995).

2) Taikabutsu Handbook, Technical Association of Refractories, Japan (1981) p. 245.

3) Technical Bulletin, "Chemistry of Organotitanium Compound and Its Application”, Ed. by Matsumoto Trading. Co., Ltd. (1980) pp. 6-7.

4) H. P. Boem, Adv. Catal., 16, 174 (1966).

5) B. McEnaey and B. Rand, Brit. Ceram. Trans. J., 84, 19398 (1985).

6) T. Nakao, "Optimum Utilization Technology of Coating", Ed. by S. Aoki, Comprehensive Research Institute in Science and Technology (1988) pp. 189-90.

7) N. Pilpel, Brit. Chem. Eng., 11, 699-702 (1966).

8) T. Otsubo, Powder Technol. Res. Soc., 2, 179-88 (1965).

9) Y. Oda, S. Shibusawa and H. Okamoto, Taikabutsu, 45, 431-32 (1993).

10) S. Okazaki, Powder and Industry, 19, No. 3, 23-32 (1987).

11) "Surface Modification Technology", Ed. by Technical Commission of Materials, Industrial Technology Service Center (1993) p. 378. 